\title{
Macroprolactinemia: new insights in hyperprolactinemia
}

\author{
Miro Kasum*, Slavko Oreskovic', Ivana Zec², Davor Jezek³, Vlatka Tomic ${ }^{3}$, Vesna Gall ${ }^{3}$, Goran Adzic ${ }^{4}$ \\ ${ }^{1}$ Department of Obstetrics and Gynaecology, University Hospital Center, School of Medicine, University of Zagreb, Zagreb, Croatia \\ ${ }^{2}$ Laboratory of Endocrinology, Clinic of Oncology and Nuclear Medicine, Sestre Milosrdnice University Hospital Center, Zagreb, Croatia \\ ${ }^{3}$ Department of Histology, School of Medicine, University of Zagreb, Zagreb, Croatia \\ ${ }^{3}$ Department of Obstetrics and Gynaecology, Sestre Milosrdnice University Hospital Center, University of Zagreb, Zagreb, Croatia \\ ${ }^{4}$ Department of Obstetrics and Gynaecology, Clinical Hospital Mostar, University of Mostar, Mostar, Bosnia and Herzegovina
}

*Corresponding author: mkasum@gmail.com

\begin{abstract}
Hypersecretion of prolactin by lactotroph cells of the anterior pituitary may lead to hyperprolactinemia in physiological, pathological and idiopathic conditions. Most patients with idiopathic hyperprolactinemia may have radiologically undetected microprolactinomas, but some may present other causes of hyperprolactinemia described as macroprolactinemia. This condition corresponds to the predominance of higher molecular mass prolactin forms (big-big prolactin, MW > $150 \mathrm{kDa}$ ), that have been postulated to represent prolactin monomer complexed with anti-prolactin immunoglobulins or autoantibodies. The prevalence of macroprolactinemia in hyperprolactinemic populations between $15-46 \%$ has been reported. In the pathophysiology of macroprolactinemia it seems that pituitary prolactin has antigenicity, leading to the production of anti-prolactin autoantibodies, and these antibodies reduce prolactin bioactivity and delay prolactin clearance. Antibody-bound prolactin is big enough to be confined to vascular spaces, and therefore macroprolactinemia develops due to the delayed clearance of prolactin rather than increased production. Although the clinical symptoms are less frequent in macroprolactinemic patients, they could not be differentiated from true hyperprolactinemic patients, on the basis of clinical features alone. Although gel filtration chromatography (GFC) is known to be the gold standard for detecting macroprolactin, the polyethylene glycol precipitation (PEG) method has offered a simple, cheap, and highly suitable alternative. In conclusion, macroprolactinemia can be considered a benign condition with low incidence of clinical symptoms and therefore hormonal and imaging investigations as well as medical or surgical treatment and prolonged follow-up are not necessary.
\end{abstract}

Key words: macroprolactin; diagnosis; clinical features; pathophysiology

\section{Introduction}

Human prolactin (PRL) is a single polypeptide hormone containing 198 amino acid residues identified in 1970. Prolactin synthesis and secretion by pituitary lactotroph cells is tonically suppressed by hypothalamic dopamine traversing the portal venous system to impinge on lactotroph D2 receptors. Factors inducing prolactin synthesis and secretion include estrogen, thyrotropin-releasing hormone (TRH), epidermal growth factor, and dopamine receptor antagonists. The stimulatory effect of PRL release in response to TRH appears rarely in cases of primary hypothyroidism. Longterm or inadequately treated primary hypothyroidism can cause pituitary hyperplasia that may mimic a pituitary tumor. Hyperprolactinemia and enlargement of the pituitary gland due to thyroid failure can be reversed by treatment with L-thyroxine. The homology of the amino acids sequence between the PRL molecule and both human growth hormone and human placental lactogen is remarkable. The structure is folded to form a globular shape and braced by the three disulfide bridg- 
es. Heterogeneity in molecular size of the human PRL molecule has been described in the human pituitary and serum. PRL is synthesized as a prehormone (MW $26 \mathrm{kDa}$ ) and after cleavage the resulting hormone is a monomeric isoform of PRL (little $\mathrm{PRL}, \mathrm{MW} 23 \mathrm{kDa}$ ). This monomeric isoform is the major circulatory form accounting for $80-95 \%$ of the total PRL and it is known be both biologically and immunologically active in vivo. The other forms mainly include the dimeric (big PRL, MW 45$60 \mathrm{Da}$ ) and the polymeric isoform (big-big PRL, $\mathrm{MW}>150 \mathrm{Da}$ ) or macroprolactin. In normal sera the dimeric isoform makes up $<10 \%$ of the PRL present and the polymeric isoform accounts for a small but variable percentage of total PRL (1). These latter two forms are known to have lower biological activity. Human macroprolactin displays low biological activity via its homologous receptor tested in Nb2 and Ba/F-LLP bioassays (2). Macroprolactin is a PRL variant with reduced bioactivity towards its homologous receptor, and this altered bioactivity may contribute to the lower disease activity and absence of symptoms related to human PRL in systemic lupus erythematosus patients (3). Hyperprolactinemia is the state of increased serum PRL concentration (> $20 \mathrm{mcg} / \mathrm{L}$ or $>580 \mathrm{mlU} / \mathrm{L}$ ) and it most commonly results from physiological or pathological conditions that cause hypersecretion of PRL by lactotroph cells. True hyperprolactinemia is characterized by the presence of excess monomeric PRL in serum. Hypersecretion of monomeric PRL leads to the classical symptoms and signs of true hyperprolactinemia which include oligomenorrhea or amenorrhea, galactorrhea, and infertility in women, loss of libido and impotence in men, and in children delayed puberty, galactorrhea, gynecomastia, and primary amenorrhea. Hyperprolactinemia occurs in $15-20 \%$ cases of women with chronic anovulatory cycles. Macroprolactinemia is defined by the predominance of serum macroprolactin together with nonpathologic monomeric PRL concentrations. Physiological conditions associated with an increased PRL release include pregnancy, puerperium, nursing, stress, pain, physical exercises, coitus, nocturnal sleep, high-protein meals and late follicular and luteal phase of menstrual cycle. Pathological hyperprolactinemia may result from a lactotroph adenoma (prolactinoma), empty sella syndrome, intracranial tumors compressing the pituitary stalk or hypothalamus, dopamine receptor D2 antagonist and PRL stimulative drugs, repetitive mechanical stimulation of breast, chest wall trauma, hepatorenal disease and primary hypothyroidism (4-6).

Nevertheless, despite an extensive clinical, hormonal and neuroradiological work-up, no cause can be found in some patients whose serum PRL concentration may remain elevated for a long time. Such patients are often categorized as having so-called idiopathic hyperprolactinemia. They are often subjected to repeated radiological examinations to find undetectable microadenomas, to a long-term treatment with dopaminergic agents (including bromocriptine, cabergoline, and quinagolide), and even to a surgical intervention. There is accumulating evidence that macroprolactinemia in which most circulating PRL forms large protein complexes (more than $150 \mathrm{kDa}$ ), is a major cause of idiopathic hyperprolactinemia. The patients with macroprolactinemia are clinically characterized by the lack of hyperprolactinemiarelated symptoms such as amenorrhea and galactorrhea $(6,7)$. Although a smaller proportion of patients with macroprolactinemia have signs and symptoms of hyperprolactinemia, galactorrhea is present in $20 \%$, oligo/amenorrhea in $45 \%$, and pituitary adenomas in $20 \%$ (8). Because macroprolactinemia is a variable cause of hyperprolactinemia, routine screening for macroprolactin could eliminate unnecessary diagnostic testing and treatment. Although the macroprolactin screening does not completely avoid inappropriate clinical investigation or associated health-costs, the average cost in patients with true hyperprolactinemia is significantly higher than in patients with macroprolactinemia. Therefore, the importance of proper medical education and knowledge diffusion of the meaning of macroprolactinemia would be desirable (9).

\section{History}

In the first description Whittaker et al. in 1981 reported an interesting case of hyperprolactinemia 
whose serum PRL was predominantly (90\%) consisting of big-big PRL (10). The clinical symptoms of hyperprolactinemia such as amenorrhea and galactorrhea were absent, with maintained fertility and spontaneous pregnancy was possible despite hyperprolactinemia. It was suggested that big-big PRL had a low receptor affinity that might account for the apparent lack of any biological effect. The predominance of the highest molecular size (150$170 \mathrm{kDa}$ ) PRL in a woman who conceived following infertility was also demonstrated in 1982 by Anderson et al. (11). They found the bioactivity of macroprolactin component in vitro and suggested that the absence of in vivo bioactivity might be the result of the big-big PRL complex preventing passage through the capillary endothelium to the target cell. Jackson et al. first used the new term „macroprolactinemia“ in 1985 to describe a patient with a three-year history of documented serum PRL levels of 350 to $400 \mathrm{ng} / \mathrm{mL}$ presenting like a pituitary tumor, but with no evidence of a pituitary adenoma on computed axial tomographic scanning (12). Analysis of circulating prolactin by column chromatography of the patient's serum revealed that greater than 85 percent of her circulating immunoreactive PRL had a molecular weight greater than $100 \mathrm{kDa}$. A reduced biological activity of macroprolactin (compared with monomeric PRL) was suggested as the reason for the lack of symptoms.

\section{Prevalence}

The proportion of macroprolactinemia in the general population has previously been reported at $0.2 \%$ in women and $0.02 \%$ in men (13). However, a recent study suggests that macroprolactinemia may be more common, with a prevalence of $3.68 \%$ and no difference in prevalence between genders. Approximately three quarters of the subjects with macroprolactinaemia had anti-prolactin autoantibodies. Glycosylation, aggregation and covalent/ noncovalent binding were also involved in the formation of macroprolactin (14). These data suggest that this condition represents an often overlooked diagnosis and a cause of hyperprolactinemia whose frequency is certainly underestimated. Re- ported proportion of macroprolactinemia in hyperprolactinemic populations in most studies varies between 15 and 35\% $(15,16)$. One study reported a prevalence of $46 \%$, but it is likely that this particular incidence reflected selection bias because of the specialized nature of the study center, which received samples sent from other laboratories when the possible diagnosis of macroprolactinemia was raised (17).

\section{Pathophysiology}

Although macroprolactinemia is heterogeneous the condition is characterized by the predominance of circulating high molecular mass PRL forms which have coupled with anti-PRL immunoglobulins. These autoantibodies have been found to be immunoglobulin (lgG) isotypes with low receptor affinity in vivo and they may be a primary cause of hyperprolactinemia. Although macroprolactin has been shown to exhibit varying degrees of biological activity in vitro, because of its high molecular mass the complex is confined to the vascular system in vivo and hence is bio-unavailable. Its high molecular weight may reduce its access to target organs in the periphery as well as centrally $(11,12,18)$. Mechanisms involved in the development of anti-PRL antibodies are still unknown. A speculation on the source of these antibodies suggests that posttranslational modifications (glycosylation and phosphorylation) of some proteins and PRL may create neo-epitopes (antibody-binding sites on the PRL molecule) for the production of antibodies (19). Hattori et al. have recently reported by examining IgG subclasses of the antibodies that the predominant form was lgG4 (20). Because lgG4 usually plays an important role in allergic conditions, it was suggested that there may also be a chronic stimulation by PRL with possible altered antigenicity in patients with anti-PRL antibodies. Their data first demonstrated that human pituitary PRL was serine phosphorylated and partially dephosphorylated in serum, suggesting that the acidic forms may give rise to chronic antigen stimulation in patients with antiPRL antibodies. If pituitary phosphorylated forms of PRL such as phosphorylated ones are intolerant 
to the immune system, leakage of such forms of PRL upon hypophysitis or lack of dephosphorylation may cause an autoimune response. These findings suggest that pituitary PRL, even if homologous, has antigenicity, leading to the development of anti-PRL autoantibodies. Several possibilities may be discussed for the cause of hyperprolactinemia in patients with anti-PRL antibodies. A positive correlation was found between the titer of anti-PRL antibodies and serum PRL level, suggesting that the autoantibodies were the cause of hyperprolactinemia. The clearance of PRL is slower in the presence of anti-PRL antibodies, suggesting that antibody-bound PRL is big enough to be confined to vascular spaces, including the prevention of the bound PRL filtration from the glomerules. Therefore macroprolactinemia develops due to the delayed clearance of PRL rather than increased production. These autoantibodies reduce PRL bioactivity and delay PRL clearance. Lastly, these PRL autoantibodies are stable with time, for at least 5 weeks, what supports the idea that macroprolactinemia is a chronic condition in humans (21). During the metoclopramide test, dimeric and monomeric PRL levels increased and rapidly returned to the basal levels, whereas macroprolactin kept increasing. This may also contribute to the pathogenesis of macroprolactinemia, due to a lack of negative feedback, because PRL-autoantibody complex cannot freely access the hypothalamus (22). Lack of macroprolactin in the pituitary tissue and in the extravascular space may be the reason for the absence of symptoms in the clinical presentation. It was reported that epitopes of anti-PRL autoantibodies in patients with macroprolactinemia were located near binding site 1 to human PRL receptors, raising a possibility that anti-PRL autoantibodies may compete with the PRL molecule for binding to its receptors, resulting in reduced bioactivity in vivo and asymptomatic clinical presentation (23). However, studies on big-big PRL biological activity in vivo are still controversial. The controversy is largely a result of the finding of substantial numbers of patients with hyperprolactinemia attributable to macroprolactin and symptoms of the hyperprolactinemic syndrome $(24,25)$. Suliman et al. argue that the symptoms and hyperpro- lactinemia attributable to macroprolactin in these cases are coincidental, whereas Olukoga suggests that the macroprolactin complex may dissociate in vivo in some cases, releasing bioactive, monomeric PRL that causes the symptoms $(16,26)$. It is, therefore, possible that increasing bioavailability of monomeric PRL due, perhaps, to intermittent dissociation from the low affinity, high capacity IgG antibody to which it is bound in macroprolactin, and/ or influence of macroprolactin in PRL secretion, may be a contributory factor to development of symptoms of PRL excess.

\section{Clinical feature}

The earliest reports of macroprolactinemia were isolated cases in patients being investigated for nonreproductive endocrine problems or healthy research volunteers who had no symptoms of hyperprolactinemia, but normal menstruation and maintained fertility $(10,11)$. Subsequently, the condition was suspected mainly when unexplained hyperprolactinemia was found without recognized symptoms of PRL excess; this situation may have helped perpetuate the notion that macroprolactinemia is essentially asymtomatic (12). However, not all patients with macroprolactinemia lack clinical symptoms because in findings of more recent clinical studies a significant proportion of patients appeared to suffer from symptoms commonly associated with true hyperprolactinemia $(24,25)$. Symptoms related to PRL excess were found in about $44 \%$ of individuals from the macroprolactinemia group and in $88.5 \%$ of patients with monomeric hyperprolactinemia (25). Circumstances leading to the diagnosis of macroprolactinemia included menstrual disorders (39\%), infertility (29\%), galactorrhea (46\%) (24). Although oligomenorrhea/amenorrhea and galactorrhea were more common in patients with true hyperprolactinemia, macroprolactinemic patients could not be differentiated from true hyperprolactinemic patients on the basis of clinical features alone. Serum levels of estradiol and LH and the LH/FSH ratio were significantly greater in macroprolactinemic compared with true hyperprolactinemic subjects. Because macroprolactinemia is a common cause of hyper- 
prolactinemia, routine screening of all hyperprolactinemic sera for macroprolactin could eliminate unnecessary diagnostic testing and treatment (27). Therefore, no clinical features could reliably differentiate macroprolactinemic from true hyperprolactinemic patients, because at least one of these symptoms was present in most macroprolactinemic patients (28). The possible association of macroprolactinemia with a pituitary tumor or other causes of hyperprolactinemia warrants a cautious initial and subsequent work-up of patients with this disorder and clearly does not allow us to limit this diagnosis to the sole field of idiopathic hyperprolactinemia (24). Although the prevalence of pituitary adenomas in macroprolactinemic patients is lower (26.7\%) compared with the true hyperprolactinemic patients $(55.4 \%)$, it may be higher than that found in other recent studies and in the general population (15-17,29-31).

Because true hyperprolactinemia and macroprolactinemia cannot be reliably distinguished on clinical criteria alone, a Task Force of The Endocrine Society suggested screening for macroprolactin in investigation of asymptomatic hyperprolactinemic subjects $(32,33)$. Routine screening of all hyperprolactinemic sera for macroprolactin is cost effective and could eliminate unnecessary diagnostic testing and treatment (27).

\section{Laboratory diagnosis}

Laboratory techniques demonstrating hyperprolactinemia are essential for the accurate diagnosis and treatment of patients. Nowadays, laboratory professionals are faced with challenging inabilities of the commercially available immunoassays to differentiate the patients with true hyperprolactinemia, due to the increased serum levels of monomeric prolactin, from those with macroprolactinemia (21). Namely, macroprolactin is detected by all immunoassays, although to varying degrees $(34,35)$. Generally, methods determining PRL have been declared as high-, medium- and lowreading for macroprolactin (35). According to earlier studies, the variability of immunoassays to detect macroprolactin in the sample depends on the disposition of the epitopes on the PRL molecule towards the antibodies used in vitro (capture antibody), supposing that different antigenic sites might be occupied by the different endogenous human antibodies (autoantibodies) (35-37). Despite the comprehensive knowledge and efforts to solve this analytical problem, manufacturers of immunoassays have failed to produce the antibody which would be directed against epitope specific only for monomeric PRL (38). Undoubtedly, good laboratory practice requires screening for macroprolactin in all hyperprolactinemic sera and determination of PRL concentrations after the removal of macroprolactin from pretreated samples. Several separation techniques have been elaborated.

Gel filtration chromatography (GFC) has been considered the reference method for the separation of macroprolactin from mono- and dimeric PRL. Chromatographic gel retains the molecules by their different molecular weight and three-dimensional shape as they pass through a column (39). Although the technique of GFC is robust and reproducible, some disadvantages preclude its widespread use in diagnostic laboratories. First, a certain amount of PRL-autoantibody complex may dissociate during the lengthy chromatographic gel filtration run, thereby leading to an underestimation of the macroprolactin in serum. Second, the estimation of the percentage of macroprolactin could be imprecise in the sequence of 30-40 discrete fractions eluted from column. Third, adsorption or denaturation of immunoreactive material during the gel filtration procedure may be selective and cause the disproportionate loss of individual isoforms of PRL in treated sample. Fourth, and maybe the most important, GFC is time-consuming, expensive technique that requires a considerable technical skill and therefore is more suitable for the research laboratories $(34,39)$.

Separation of macroprolactin by immunoadsorption with Protein A (PA) and Protein G (PG), immobilized on Sepharose, is based on high affinity of PA and PG for human IgG, which is a primary antibody to PRL in serum. After incubation, immuno complexes between PA or PG and macroprolactin in an aliquot of serum are precipitated by centrifugation and the concentration of monomeric PRL is measured in supernatant. Although this method 
exhibits acceptable precision and the recovery of standard preparation is satisfactory, some of the authors have shown that pretreatment of sera with PA and PG leads to a significant overestimation of monomeric PRL concentrations $(39,40)$. Such a divergence of results from target limits the usefulness of this method for removal of macroprolactin from serum.

Separation of macroprolactin by means of ultrafiltration is based on the passage of PRL through the separating membrane which selectively retains particles according to their molecular size, net charge and three-dimensional structure. Serum sample is diluted with phosphate buffered saline (PBS) and subjected to a filter device and the unit is centrifuged at the recommended speed and the duration of time. Concentration of monomeric PRL is measured in ultrafiltrated and original sample; results are then calculated as percentage of recovery of PRL $(41,42)$. Although, ultrafiltration represents a practical and precise alternative to GFC for estimating the macroprolactin in serum, the PRL concentrations recorded after ultrafiltration, compared with those after GFC, may vary considerably from sample to sample $(39,42)$.

Number of studies has shown that polyethylene glycol (PEG) induced precipitation of macroprolactin in serum sample may represent a simple, accessible and reproducible screening technique for hyperprolactinemic sera (43-45). Detailed description of PEG separation method has been reported by several authors $(39,42,44,46)$. The method is based on different precipitation of proteins according to their molecular weight and solubility in aqueous PEG solution. It has been generally accepted that PRL recovery of $40 \%$ of its initial value, after PEG treatment, indicates the presence of macroprolactin in patient's serum, although the thresholds vary between $<30-50 \%(46,47)$. Precipitation with PEG is widely used screening test for macroprolactin and is easily performed in clinical laboratories. However, PEG also induces a partial precipitation of monomeric PRL (up to $25 \%$ ) so reliance on the relative percentage of recovery lacks specificity which may lead to an underestimated evaluation and misinterpretation of actual PRL levels (39). This is especially important in cases when an excessive macroprolactin occurs in patient's serum simultaneously with supraphysiological concentrations of monomeric PRL. Furthermore, it has been reported that the presence of PEG in the sample can interfere with some PRL immunoassay procedures (48). To avoid such problems, it has been recommended that each laboratory, undertaking macroprolactin screening, has to establish method-specific reference intervals derived by use of PEGtreated sera from healthy individuals (44-46). So, in routine laboratory diagnostics the post-PEG modified reference range is the best means to accurately identify patients with true hyperprolactinemia (46).

It is also worth to mention that the standardization of the PRL assays can contribute to the confusion when comparing results between various methods, because of the different reference preparations and units in use. Concentrations of serum PRL have been expressed in mass ( $\mu \mathrm{g} / \mathrm{L}$ or $\mathrm{ng} / \mathrm{mL})$, molar (nmol/L or pmol/L) or international units $(\mathrm{mlU} / \mathrm{L})$. Most of the current assays have been calibrated against the Third International Standard for Prolactin (WHO $3^{\text {rd }}$ IS 84/500). According to this standard preparation, $2.5 \mu \mathrm{g}$ of lyophilized human PRL has been assigned as the activity of $0.053 \mathrm{ln}$ ternational Units of PRL. Concentration of $1 \mathrm{mIU} / \mathrm{L}$ can be converted to $\mu \mathrm{g} / \mathrm{L}$ by dividing with 21.2 (45). Some of the assays have been standardized against the $2^{\text {nd }}$ IS 83/562 (49).

It seems unlikely that any of the techniques for macroprolactin determination can be used to screen all the samples analyzed in the clinical biochemistry laboratory. In the reality, detection of macroprolactin and awareness of interferences, distinctive to particular methods, usually come out as a consequence of incongruity between biochemical results and clinical validation. Still, for the accurate and early-stage diagnosis of macroprolactinemia clinical symptoms should be a starting point for clinical biochemists. On one side, it implies a close communication between a laboratory and clinicians and on the other, manufacturers supplying the PRL immunoassays should incorporate all interference data, validated protocols and guidelines for macroprolactin screening. At the same time, it includes the assumption that labora- 
tories undertaking PRL analyses inform clinicians about the characteristics and limitations of the assay in use.

\section{Conclusion}

In today's health care system the prevalence of medical errors of about $10 \%$ in clinical medical laboratories has been consistently reported. Most of these errors occur in the pre-analytical phase. Because only a small number of errors will be seen in the analytical phase, it is very likely that these might be very often ignored. The knowledge of analytical interferences and critical sample quality will offer valuable solutions to improve the global quality of the total testing process. The impact of errors in the analytical process will be better understood and the examples will help reducing the number of analytical errors and interferences, so that a much better patient safety can be granted (50). This article shows how important is a good communication between laboratory and clinician. Both laboratory professionals and clinicians should continuously aim to reduce medical errors and enhance patient safety by minimizing the risk of patient misdiagnosis. The knowledge of the ways to diagnose and interpret macroprolactinemia means benefit for the patient safety. All the patients with

\section{References}

1. Yen SSC. Prolactin in human reproduction. In: Yen SSC, Jaffe RB, eds. Reproductive endocrinology. Philadephia: WB Saunders company; 1986. p. 237-63.

2. Glezer A, Soares CR, Vieira JG, Giannella-Neto D, Ribela MT, Goffin V, Bronstein MD. Human macroprolactin displays low biological activity via its homologous receptor in a new sensitive bioassay. J Clin Endocrinol Metab 2006;91:104855 .

3. Cárdenas-Mondragón G, Ulloa-Aguirre A, Isordia-Salas I, Goffin V, Leaños-Miranda A. Elevated serum bioactive prolactin concentrations in patients with systemic lupus erythematosus are associated with disease activity as disclosed by homologous receptor bioassays. I Rheumatol 2007;34:1514-21.

4. Sluijmer AV, Lapohohn RE. Clinical history and outcome of 59 patients with idiopathic hyperprolactinemia. Fertil Steril 1992;58:72-7. hyperprolactinenia radiographic data incompatible with their PRL levels with no regard to clinical symptoms should be routinely screened for the presence of macroprolactin to avoid unnecessary investigations, incorrect diagnosis and inappropriate dopamine agonist treatment. However, when excess macroprolactin occurs simultaneously with increased concentrations of monomeric PRL the priority for the laboratory should be to determine whether the bioactive monomeric PRL concentration is increased rather than simply to measure the percentage of macroprolactin present. The presence of excess monomeric prolactin is of overriding concern, and a diagnosis of macroprolactinemia in this setting is misleading and inappropriate. However, the patients with macroprolactinemia and normal concentrations of monomeric PRL would cause less anxiety and they can be reassured without extented investigations during prolonged follow-up. It is unavoidable to alert endocrinologists, gynecologists, pharmacologists and also general practioners and all those involved in the management of hyperprolactinemia to macroprolactin, its frequent occurrence and its timely recognition.

\section{Potential conflict of interest}

None declared.
5. Speroff L. Amenorrhea. In: Speroff RH, Kase NG, eds. Clinical Gynecological Endocrinology and Infertility. Baltimore: WiIliams and Wilkins; 1989. p. 165-211.

6. Lindstedt $G$. Endogenous antibodies against prolactin: $a$ "new" cause of hyperprolactinemia. Eur J Endocrinol 1994;130:429-32.

7. Hattori N. Macroprolactinemia: a new cause of hyperprolactinemia. J Pharmacol Sci 2003; 92:171-7.

8. Donadio F, Barbieri A, Angioni R, Mantovani G, Beck-Peccoz $P$, Spada A, Lania AG. Patients with macroprolactinaemia: clinical and radiological features. Eur J Clin Invest 2007;37:552-7.

9. de Soarez PC, Souza SC, Vieira JG Ferraz MB. The effect of identifying macroprolactinemia on health-care utilization and costs in patients with elevated serum prolactin levels. Value Health 2009;12:930-4. 
10. Whittaker PG, Wicox T, Lind T. Maintained fertility in a patient with hyperprolactinemia due to big-big prolactin. J Clin Endocrinol Metab 1981;53:863-6.

11. Anderson $A N$, Pedersen $H$, Djursing $H$, Andersen BJ, Friesen HG. Bioactivity of prolactin in a woman with an excess of large molecular size prolactin, persistent hyperprolactinemia and spontaneous conception. Fertil Steril 1982;38:625-8.

12. Jackson RD, Wortsman J, Malarkey WB. Macroprolactinemia presenting like a pituitary tumor. Am J Med 1985;78:346-50.

13. Bjoro T, Makrid L, Wergerland R, Turter A, Kvistborg A, Sand $T$. Frequency of hyperprolactinemia due to large molecular weight prolactin (150-170 kD PRL) Scand J Clin Lab Invest 1995; 55:139-47.

14. Hattori N, Ishihara T, Saiki Y. Macroprolactinemia prevalence and aetilogies in a large group of hospital workers. Clin Endocrinol (Oxf) 2009;71:702-8.

15. Fahie-Wilson MN, Soule SG. Macroprolactinemia contribution to hyperprolactinemia in a district general hospital and evaluation of a screening test based on precipitation with polyethylene glycol. Ann Clin Biochem 1997;34:252-8.

16. Suliman AM, Smith TP, Gibney J, McKenna TJ. Frequent misdiagnosis and mismanagement of hyperprolactinemic patients before the introduction of macroprolactin screening application of a new strict laboratory definition of macroprolactinemia. Clin Chem 2003;49:1504-9.

17. Hauache $O M$, Rocha AJ, Maia AC, Maciel RM, Vieira JG. Screening for macroprolactinemia and pituitary imaging studies. Clin Endocrinol (Oxf) 2002;57:327-31.

18. Bonhoff A, Vuille JC, Gomez F, Gellersen B. Identification of macroprolactin in a patient with asymptomatic hyperprolactinemia as a stable -lgG complex. Exp Clin Endocrinol Diabetes 1995;103:252-5.

19. Coudevylle N, Rokas D, Sakarellos-Daitsiotis M, Krikorian D, Panou-Pomonis E, Sakarellos C, et al. Phosphorylated and nonphosphorylated epitopes of the La/SSB autoantigen: comparison of their antigenic and conformational characteristics. Biopolymers 2006;84:368-82.

20. Hattori N, Ikekubo K, Nakaya Y, Kitagawa K, Inagaki C. Immunoglobulin $G$ subclasses and prolactin (PRL) isoforms in macroprolactinemia due to anti-PRL autoantibodies. J Clin Endocrinol Metab 2005;90:3036-44.

21. Hattori N, Nakayama N, Kitagawa K, Li T, Inagaki C. Development of anti-PRL (Prolactin) autoantibodies by homologous $P R L$ in rats: a model for macroprolactinemia. Endocrinology 2007; 148:2465-70.

22. De Marinis L, Mancini A, Minnielli S, Masala R, Anile C, Maira $G$, Barbarino A. Evaluation of dopaminergic tone in hyperprolactinemia. III. Thyroid-stimulating hormone response to metoclopramide in differential diagnosis and postoperative follow-up of prolactinoma patients. Metabolism 1985;34:917-22.

23. Hattori N, Nakayama Y, Kitagawa K, Ishihara T, Saiki Y, Inagaki C. Anti-prolactin (PRL) autoantibody binding sites (epitopes) on PRL molecule in macroprolactinemia. J Endocrinol 2006;190:287-93.
24. Vallette-Kasic S, Morange-Ramos I, Selim A, Gunz G, Morange $S$, Enjalbert $A$, et al. Macroprolactinemia revisited: a study on 106 patients. J Clin Endocrinol Metab 2002;87: 581-8.

25. Vilar L, Naves LA, Freitas MC, Lima M, Canadas V, Albuquerque JL, et al. Clinical and laboratory features greatly overlap in patients with macroprolactinemia or monomeric hyperprolactinemia. Minerva Endocrinol 2007;32:79-86.

26. Olukoga AO. Macroprolactinemia is clinically important. $J$ Clin Endocrinol Metab 2002;87:4833-4.

27. Gibney J, Smith TP, McKenna TJ. The impact on clinical practice of routine screening for macroprolactin. J Clin Endocrinol Metab 2005;90:3927-32.

28. Can M, Guven B, Atmaca H, Acikgoz S, Mungan G. Clinical characterization of patients with macroprolactinemia and monomeric hyperprolactinemia. Kaohsiung J Med SCi 2011;27:173-6.

29. Tamer G, Telci A, Mert M, Uzum AK, Aral F, Tanakol R. Prevalence of pituitary adenomas in macroprolactinemic patients may be higher than it is presumed. Endocrine 2012;41:138-43.

30. Chalal J, Schlechte J. Hyperprolactinemia. Pituitary 2008; 11:141-6.

31. Hong JW, Lee MK, Kim SH, Lee EJ. Discrimination of prolactinoma from hyperprolactinemic nonfunctioning adenoma. Endocrine 2010;37:140-7.

32. Melmed S, Casanueva FF, Hoffman AR, Kleinberg DL, Montori VM, Janet $A$, et al. Diagnosis and Treatment of Hyperprolactinemia: An Endocrine Society Clinical Practice Guideline. J Clin Endocrinol Metab 2011;96:273-88.

33. Koch L. New Endocrine Society guideliness for hyperprolactinemia piecing together the pituitary puzzle. Nat Rev Endocrinol 2011;7:247.

34. Gibney J, Smith TP, McKenna TJ. Clinical relevance of macroprolactin. Clin Endocrinol 2005;62:633-43.

35. Gilson G, Schmit P, Thix J, Hoffman JP, Humbel RL. Prolactin results for samples containing macroprolactin are method and sample dependent. Clin Chem 2001;47:331-3.

36. Smith TP, Suliman AM, Fahie-Wilson MN, McKenna TJ. Gross variability in the detection of prolactin in sera containing big-big prolactin (macroprolactin) by commercial immunoassays. J Clin Endocrinol Metab 2002;87:5410-5.

37. Dodig S. Interferences in quantitative immunochemical methods. Biochem Med 2009; 19:50-62.

38. Fahie-Wilson MN. Detection of macroprolactin causing hyperprolactinemia in commercial assays for prolactin. Clin Chem 2000;46:2023-4.

39. Kavanagh L, McKenna TJ, Fahie-Wilson MN, Gibney J, Smith TP. Specificity and clinical utility of methods for the detection of macroprolactin. Clin Chem 2006;52:1366-72.

40. Smith TP, Gibney J, Kavanagh L, Fahie-Wilson M, McKenna TJ. Specificity and clinical utility of methods for the detection of macroprolactin. Irish J Med Sci 2003;172 (Suppl.1):15-6.

41. Quinn AM, Rubinas TC, Garbincius CJ, Holmes EW. Determination of ultrafilterable prolactin: Elimination of macroprolactin interference with a monomeric prolactin-selective sample pretreatment. Arch Pathol Lab Med 2006;130:1807-12. 
42. Beda-Maluga K, Pisarek H, Komorowski J, Pawlikowski M, Świętosławski J, Winczyk K. The detection of macroprolactin by precipitation and ultrafiltration methods. Endokrynol Pol 2011;62:529-36.

43. Fahie-Wilson M, Brunsden P, Surrey J, Everitt A. Macroprolactin and the Roche Elecsys prolactin assay: characteristics of the reaction and detection by precipitation with polyethylene glycol. Clin Chem 2000;46:1993-5.

44. Espinoza JR, Trigos-Landa A, Bocanegra-Garcia V, AcostaGonzález RI, Bocanegra-Alonso A, Rivera-Sánchez G. Assessment of macroprolactin after polyethylene glycol precipitation in two commercial Immunoassay. Bioquimia 2006;31:140-5.

45. Beltran L, Fahie-Wilson MN, McKenna TJ, Kavanagh $L$, Smith TP. Serum Total prolactin and monomeric prolactin reference intervals determined by precipitation with polyethylene glycol: evaluation and validation on common immunoassay platforms. Clin Chem 2008;54:1673-81.
46. McCudden CR, Sharpless JR, Grenache DG. Comparison of multiple methods for identification of hyperprolactinemia in the presence of macroprolactin. Clin Chim Acta 2010;411:155-60.

47. Leslie H, Courtney $C H$, Bell PM, Hadden DR, McCance DR, Ellis $P K$, et al. Laboratory and clinical experience in 55 patients with macroprolactinemia identified by a simple polyethylene glycol precipitation method. J Clin Endocrinol Metab 2001;86:2743-6.

48. Fahie-Wilson $M$, Halsall D. Polyethylene glycol precipitation: proceed with care. Ann Clin Biochem 2008;45:233-5.

49. WHO International Standard Prolactin, Human. NIBSC code: 84/500 Instructions for use (Version 3.0, Dated 10/12/2007) Available at: http://www.nibsc.ac.uk/documents/ifu/84-500.pdf. Accessed March 8, 2012.

50. Sonntag O. Quality in the analytical phase. Biochem Med 2010;20:147-53.

\section{Makroprolaktinemija: novi uvidi u hiperprolaktinemiji}

\section{Sažetak}

Pojačana sekrecija prolaktina od strane laktotropnih stanica adenohipofize dovodi do hiperprolaktinemije u fiziološkim, patološkim i idiopatskim stanjima. Kod većine bolesnica s idiopatskom hiperprolaktinemijom radiološki se ne otkrivaju mikroprolaktinomi, a kod nekih se nalaze drugi razlozi hiperprolaktinemije pod nazivom makroprolaktinemija. Ovakvom stanju najviše pridonosi visoko molekularni oblik prolaktina (veliki prolaktin, Mr 50 kDa i uglavnom veliki-veliki prolaktin, $\mathrm{Mr}>150 \mathrm{kDa}$ ), za kojeg se pretpostavlja da ga čne monomeri prolaktina spojeni s antiprolaktinskim imunoglobulinima ili protutijelima. Pojavnost makroprolaktinemije kreće se između 15-46\% u populaciji s hiperprolaktinemijom. U patofiziologii makroprolaktinemije čini se da prolaktin iz adenohipofize ima antigenost, koja dovodi do stvaranja antiprolaktinskih protutijela koji prolaktinu smanjuju bioaktivnost $i$ usporavaju klirens. Kako je spoj prolaktina i protutijela dostatno velik ograničen je na vaskularni prostor te stoga nastaje makroprolaktinemija prije zbog usporenog klirensa nego pojačanog stvaranja. lako su klinički simptomi rjeđi u bolesnica s makroprolaktinemijom ne mogu se razlikovati od bolesnica s pravom hiperprolaktinemijom samo na temelju kliničke slike. Premda se kromatografska filtracija gelom (GFK) smatra zlatnim standardom u detekciji prolaktina, ipak metoda precipitacije polietilen glikolom (PEG) predstavlja jednostavnu, jeftinu i visoko prikladnu metodu. Zaključujemo da se makroprolaktinemija može smatrati benignim stanjem s malom pojavnošću kliničkih simptoma zbog čega su nepotrebne hormonske i radiološke pretrage, a isto tako medikamentozno i kirurško liječenje i dugotrajno praćenje.

Ključne riječi: makroprolaktin; dijagnoza; klinička slika; patofiziologija 